\title{
Establishment of Hevea brasiliensis lines overexpressing genes involved in ethylene signalling pathway
}

\author{
Perakitan tanaman Hevea brasiliensis transgenik melalui overekspresi gen yang terlibat dalam jalur sinyal \\ etilen \\ Retno LESTARI ${ }^{\left.1,2,3^{*}\right)}$, Maryannick RIO ${ }^{1)}$, Florence MARTIN ${ }^{1)}$, Julie LECLERCQ $^{1)}$, Florence \\ DESSAILLY ${ }^{1)}$, SUHARSONO $^{3)}$, \& Pascal MONTORO ${ }^{1 *}$ \\ ${ }^{1}$ CIRAD, UMR AGAP, F-34398 Montpellier, France \\ ${ }^{2}$ University of Indonesia (UI), Depok 16424, Indonesia \\ ${ }^{3}$ Bogor Agricultural University (IPB), Bogor 16680, Indonesia
}

Diterima tanggal 8 Juni 2016 /disetujui tanggal 17 Oktober 2016

\begin{abstract}
Abstrak
Gas etilen merupakan hormon pada tumbuhan yang telah banyak digunakan dalam pengembangan pertanian dan hortikultura. Sebagian besar kerja beberapa gen yang responsif terhadap hormon etilen dikendalikan oleh faktor transkripsi yang disebut Ethylene Response Factors (ERF). Dua faktor transkripsi pada tanaman Hevea HbERF-IXc4 dan HbERFIXc5 merupakan gen yang ortholog dengan ERF1 pada Arabidopsis thaliana. ERF1 merupakan faktor yang mengatur integrasi sinyal antara etilen dan jasmonat. Kedua gen tersebut diduga berperan dalam pengaturan metabolisme sel lateks pada proses penyadapan dan stimulasi ethephon. Tanaman transgenik Hevea yang mengandung dua gen HbERF-IXc4 dan HbERFIXc5 di bawah kendali promoter 35S CaMV dan HEV2.1 telah berhasil dirakit menggunakan metode transformasi genetik melalui Agrobacterium tumefaciens. Transformasi genetik melalui perantara A. tumefaciens dikembangkan menggunakan material kalus remah dari klon PB260. Agregat kalus Hevea tersebut kemudian disubkultur ke dalam medium yang mengandung paromomisin. Kalus transgenik yang diperoleh menunjukkan hasil yang positif dalam uji aktivitas GFP dengan metode Southern blot. Sembilan galur transgenik dikonfirmasi telah terinsersi gen HbERF-IXc4 dan HbERF-IXc5, dimana tujuh di antaranya hanya mengandung satu kopi T-DNA. Regenerasi dan karakterisasi dari tanaman transgenik perlu dilakukan untuk memahami fungsi HbERF-IXc4 dan HbERF-IXc5 yang diduga berperan dalam produksi lateks.
\end{abstract}

[Kata kunci: etilen, ethylene response factor, embriogenesis somatik, karet, faktor transkripsi, tanaman transgenik]

\footnotetext{
${ }^{*}$ Penulis korespondensi: pascal.montoro@cirad.fr
}

\begin{abstract}
The gaseous plant hormone ethylene has a wide variety of applications in agriculture and horticulture. Ethylene Response Factors (ERF) are the last transcription factors of the ethylene signalling pathway and control a large number of ethylene-responsive genes. Two Hevea brasiliensis ERF, HbERF-IXc4 and HbERF-IXc5, are orthologs to $E R F 1$, a key regulator at the crosstalk of ethylene and jasmonate signalling pathways. These genes were suggested to play an important role in regulating latex cell metabolism in response to tapping and ethephon stimulation. In this study, transgenic lines overexpressing $H b E R F-I X c 4$ and $H b E R F-I X c 5$ under control of $35 S C A M V$ and HEV2.1 promoter have been conducted. Transgenic Hevea lines were obtained by Agrobacterium tumefaciens-mediated genetic transformation. The somatic embryogenesis process was affected by these modifications. Agrobacterium tumefaciens genetic transformation procedure has been developed from friable callus line for clone PB260. Hevea callus was sub-cultured as small aggregates on paromomycin selection medium. Transgenic callus lines established from sub-aggregates showing full GFP activity. The insertion of HbERF-IXc4 and $H b E R F-I X c 5$ genes were confirmed by Southern blot hybridization in nine transgenic lines, and seven of these lines have only one T-DNA copy. Further plant regeneration and characterization were necessary to understand the function $H b E R F-I X c 4$ and HbERF-IXc5 in latex production.
\end{abstract}

[Keywords: ethylene, ethylene response factor, somatic embryogenesis, rubber, transcription factor, transgenic lines]

\section{Introduction}

Hevea brasiliensis (Willd. ex A. Juss.) Müll Arg. is the source of natural rubber (NR), which is synthesized in latex cells. NR is an 
important industrial material for transportation, consumer, and medical. The demand for NR is increasing from year to year. Nowadays, about 93\% of NR world supplies is produced in Asia, Africa (4\%), and Latin America (3\%). The largest NR producing countries are Thailand (38\%), Indonesia $(30 \%)$, and Vietnam $(9 \%)$. NR is the main product from $H$. brasiliensis which is obtained from latex in laticifer after tapping the bark.

Ethylene is an important hormone to stimulate latex production in rubber tree (Clément-Demange et al., 2007; Putranto et al., 2015; Vaysse et al., 2012). The ethylene signalling pathway activates the Ethylene Response Factor (ERF) transcription factors. $E R F$ genes are associated with response to abiotic and biotic stresses. ERF1 was suggested to be a key component for the defence responses through the integration of ethylene (ET) and jasmonic acid (JA) signalling pathways (Benavente \& Alonso, 2006; Lorenzo et al., 2003; Wasternack \& Hause, 2013). The crosstalk between ET and JA signalling pathways acts together synergistically during plant defence against herbivores, necrotrophic fungi infections, plant pathogens, and in responses of wounding (Lorenzo et al., 2003; Zhu \& Lee, 2015). Crosstalk connection between pathways in plants could be interpreted as the interaction between specific signal transduction pathways which resulted in a rapid and efficient mechanism for optimizing non-cognitive behaviour in response to various combinations of stimuli (Weiss and Ori, 2007).

Several genes in $H$. brasiliensis were regulated independently in signalling pathways. Defence responses in Hevea were dramatically mediated by wounding, methyl jasmonate (MeJA), and ethylene (ET) (Duan et al., 2010). Two Hevea ERF, HbERF-IXc4 and HbERF$I X c 5$, are orthologs to ERF1 a key regulator at the crosstalk of ethylene and jasmonate signalling pathways (Duan et al., 2013; Piyatrakul et al., 2014; Putranto et al., 2015). Functional analysis

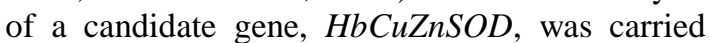
out in Hevea (Leclercq et al., 2012), with both somatic embryogenesis and A. tumefaciensmediated genetic transformation procedures (Blanc et al., 2006; Leclercq et al., 2010). One of commonly used promoters is the $35 \mathrm{~S}$ RNA promoter sequence from the Cauliflower Mosaic Virus (CaMV) (Wu et al., 2014). In the other hand, promoter of the HEV2.1 gene was reported to drive expression in latex and leaves (Montoro et al., 2008). This paper aims to establish $H$. brasiliensis transgenic lines for the two recently identified transcription factors HbERF-IXc4 and HbERF-IXc5 under the control of $35 \mathrm{~S} \mathrm{CaMV}$ or latex-specific $H E V 2.1$ promoter.

\section{Materials and methods}

The construct used for this transformation experiment consisted of a binary pCamway 2300 vector with the cassette harbouring GFP gene, NPTII gene, and one candidate gene (Leclercq et al., 2015). In this study, HbERF-IXc4 and $H b E R F-I X c 5$ genes were cloned under the control of 35S CaMV or HEV2.1 promoter (Duan et al., 2013; Leclercq et al., 2010; Montoro et al., 2008). The binary vectors were introduced into $A$. tumefaciens strain EHA105 by electroporation. Plant material used in this study was the friable callus line CI07060 from clone PB 260, which was established from integument calli (Lardet et al., 2009). This callus line was sub-cultured every two weeks on a maintenance culture medium (MM). After getting the transgenic cell, the process was continued by using the green fluorescent protein (GFP) selection as a visual marker (Leclercq et al., 2010). The GFP visualisation was performed under a fluorescent stereo microscope (MZ FLIII, Leica Microsystems, Wetzlar, Germany). The production of embryos and their conversion into plantlets were carried out as described by Lardet et al. (2007). The development of pro-embryos was then carried out in a temporary immersion system (RITA ${ }^{\circledR}$, CIRAD, Montpellier, France). For plant regeneration, well-shaped mature embryos were collected and transferred to DEV3 medium for germination (Lardet et al., 2007).

Southern-blot hybridization analysis were conducted to verify the insertion and overexpression of two candidate genes ( $H b E R F$ IXc4 and HbERF-IXc5) into Hevea transgenic plants genome. DNA extraction from leaves of transgenic lines was conducted as described in Leclercq et al. (2010). Samples of genomic DNA were fragmented with EcoR1 restriction enzyme and fractionated by electrophoresis in a $0.8 \%$ agarose gel in TAE buffer. The hybridization was performed as described in Sambrook et al. (1989) using random primed ${ }^{32} \mathrm{P}$ radio-labelled probes corresponding to NPTII gene (Amersham ${ }^{\mathrm{TM}}$ Megaprime DNA Labelling System, Buckinghamshire, UK).

\section{Results and Discussion}

Hevea callus was successfully sub-cultured as small aggregates on paromomycin selection medium (Figure 1A). Somatic embryogenesis was initiated for 4 weeks by sub-culturing $1 \mathrm{~g}$ of callus showing full GFP activity on semi-solid embryogenesis expression medium (EXP). All GFP-positive lines were obtained from DM medium then continued to transfer on EXP medium (Figure $1 \mathrm{~B}$ and 1C). Pro-embryo development was carried out in a temporary immersion system (RITA ${ }^{\circledR}$, CIRAD, Montpellier) 
for 4 weeks with 1 min of immersion per day in the liquid development medium (DEV) (Figure 1D). Each RITA was considered as an experimental replication. Conversion of mature embryos was carried out according to Lardet et al. (1999). Well-shaped mature embryos were produced (Figure 1E). Plantlets were successfully derived from normal embryos (Figure 1F).

Twenty-nine GFP-positive lines were established and cryopreserved for $35 S:: H b E R F$ IXc4 (5 lines), HEV2.1::HbERF-IXc4 (6 lines), $35 S:: H b E R F-I X c 5$ (7 lines) and HEV2.1::HbERFIXc5 (11 lines) (Table 1). Plantlets were regenerated for wild-type and 12 of the 29 GFPpositive lines. Regeneration efficiency (number of plantlets/RITA) is lower for transgenic plants compared to wild-type, and it was very low for lines harbouring $35 S:: H b E R F-I X c 4$. Southern-blot molecular hybridization was performed using NPTII gene probe and DNA samples from plants of 9 GFP-positive lines and one negative control (wild-type) (Table 2). All these transgenic lines have 1 copy of the T-DNA except transgenic lines TS18A69 and TS18A09, which have 2 and 3 copies, respectively.

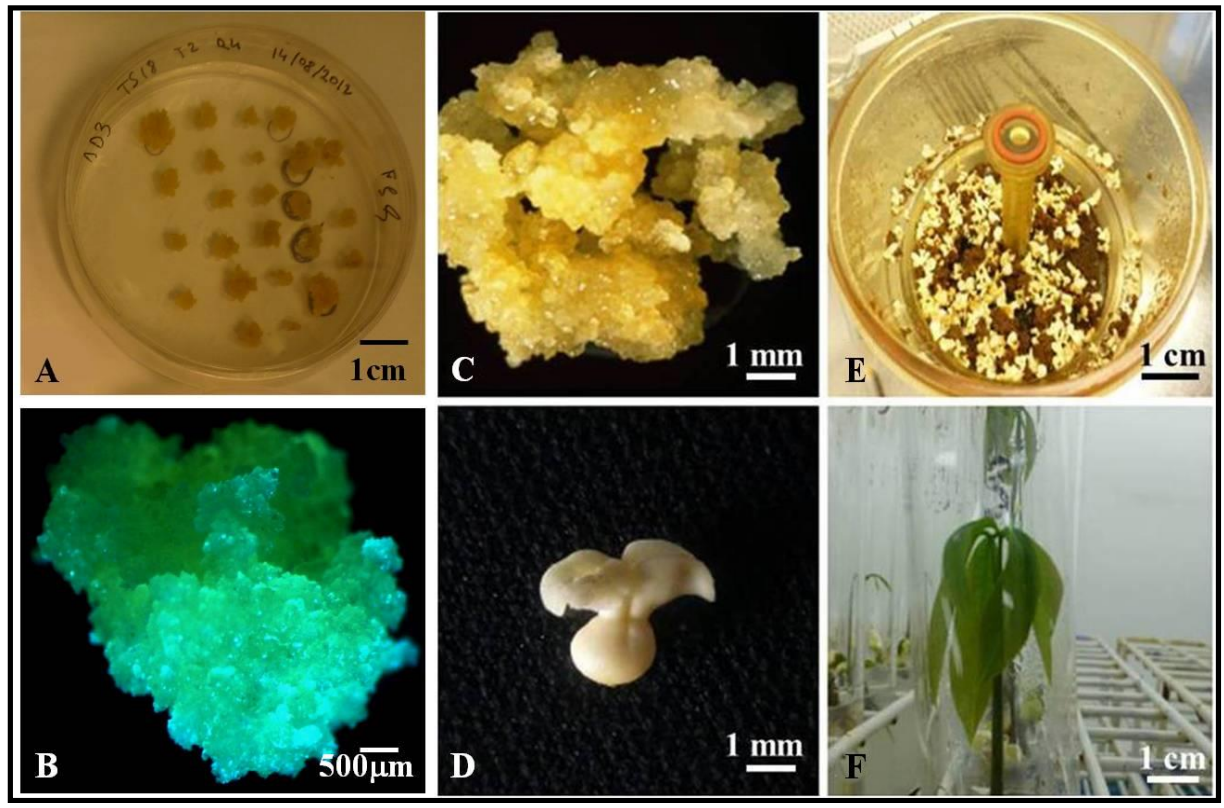

Figure 1. Somatic embryogenesis of H. brasiliensis. (A) paromomycin-resistant calli with GFP positive aggregates, (B) GFP fluorescence in callus, (C) Transgenic callus line, (D) Embryos from transgenic callus line, (E) Wellshaped mature embryo, (F) Transgenic plantlet.

Gambar 1. Embriogenesis somatik tanaman H. brasiliensis. (A) Kalus GFP positif resistan terhadap paromomycin, (B) GFP fluoresens pada kalus, (C) Kalus transgenik, (D) Embrio dari kalus transgenik, (E) Embrio dengan morfologi baik, $(F)$ Planlet transgenik.

Table 1. Number of GFP-positive lines and their regeneration capacity.

Tabel 1. Jumlah transgen yang positif terhadap penanda GFP dan kemampuan regenerasinya.

\begin{tabular}{cccc}
\hline $\begin{array}{c}\text { Candidate gene } \\
\text { Gen kandidat }\end{array}$ & $\begin{array}{c}\text { GFP-positive lines (No) } \\
\text { Galur GFP positif(No) }\end{array}$ & $\begin{array}{c}\text { Line regenerating plantlets (No) } \\
\text { Planlet hasil regenerasi (No) }\end{array}$ & $\begin{array}{c}\text { Plantlet/RITA (No) } \\
\text { Planlet/RITA (No) }\end{array}$ \\
\hline None & 0 & 1 & 11.94 \\
$35 S:: H b E R F-I X c 4$ & 5 & 2 & 0.12 \\
$H E V 2.1:: H b E R F-I X c 4$ & 6 & 5 & 9.44 \\
$35 S:: H b E R F-I X c 5$ & 7 & 2 & 7.53 \\
$H E V 2.1:: H b E R F-I X c 5$ & 11 & 3 & 7.82 \\
\hline
\end{tabular}


Table 2. Southern-blot molecular hybridization analysis of DNA from wild-type (CI07060) and transgenic lines using NPTII probe.

Tabel 2. Analisis molekular DNA dari wild-type (CI07060) dan tanaman transgenik dengan metode Southern-blot hibridisasi dengan NPTII probe.

\begin{tabular}{ccc}
\hline Construct/ Konstruk & Line/ Galur & $\begin{array}{c}\text { T-DNA(No of copy)/ } \\
\text { T-DNA (Jumlah kopi) }\end{array}$ \\
\hline Wild-type & CI07060 & 0 \\
$35 S:: H b E R F-I X c 4$ & TS17A61 & 1 \\
& & 3 \\
HEV2.1::HbERFIXc4 & TS18A09 & 1 \\
& TS18A13 & 1 \\
$35 S:: H b E R F I X c 5$ & TS18A37 & 2 \\
& TS18A69 & 1 \\
HEV2.1::HbERF-IXc5 & TS19A46 & 1 \\
& TS19A90 & 1 \\
\hline
\end{tabular}

In this study, transgenic lines harbouring two genes (HbERF-IXc4 and HbERF-IXc5) were successfully transformed under control of $35 \mathrm{~S}$ $C a M V$ and HEV2.1 promoters. This experiment used four constructs described as: $35 S:: H b E R F$ IXc4, HEV2.1::HbERF-IXc4, 35S::HbERF-IXc5, and HEV2.1::HbERF-IXc5. The transgenic lines under the construct $35 S:: H b E R F-I X c 4$ showed low plant regeneration. This suggests that $H b E R F-I X c 4$ has a negative effect on plant regeneration when driven by $35 \mathrm{~S} \mathrm{CaMV}$.

The role of gene regulatory regions (promoters) is important for understanding the regulation of plant gene expression. Both of promoters have been demonstrated to drive a candidate gene in genetic transformation via $A$. tumefaciens (Blanc et al. 2006; Montoro et al. 2000; Rattana et al. 2001). The $35 \mathrm{~S} \mathrm{CaMV}$ promoter allows strong constitutive expression in all tissues, in the other hand HEV2.1 promoter allows targeted expression in laticifer cells and in leaves (Montoro et al., 2008).

Twenty-nine GFP-positive lines were established on paromomycin selection medium. Paromomycin is more efficient than kanamycin for the selection of transformed cells and can inhibit the growth of non-transformed cells more quickly (Montoro et al., 2003; Perez-Barranco et al., 2009). Nine lines were confirmed by Southern blot hybridization and seven of these lines have only one T-DNA copy. This revealed that the genetic modification methodology did not affect too much the Hevea genome compared to other procedures using particle bombardment or too virulent Agrobacterium strains. For that reason, most of transgenic lines can be compared to each other without any strong effect of the copy number. Each line with one copy of T-DNA had a higher gene expression of their corresponding transgene.
HbERF-IXc4 gene having lower callus proliferation was observed with the $35 \mathrm{~S} \mathrm{CaMV}$ promoter compared to HEV2.1. For instance, $H b E R F-I X c 4$ gene with $35 S$ CaMV need more subcultures than with $H E V 2.1$ to get a sufficient quantity of callus for further plant regeneration and callus cryopreservation. All lines could produce abundant yellow callus. At the beginning of culture, the callus appeared creamy in colour and then gradually became yellow or dark yellow. Finer (1988) has been classified the cotyledon callus based on the colour as green, yellow, white, brown, and red. Only yellow callus could produce embryonic culture (Finer, 1988; Perera and Dahanayake 2015; Sen et al., 2014). Callus turned brown at the advance of embryo formation. Brown calli produced a large number of somatic embryos compared to yellow calli. The abnormal types of embryos cannot develop into plantlet. Some studies verified that the constitutive promoter $35 S \mathrm{CaMV}$ is a weak promoter for transgene expression in young olive somatic embryos. This promoter was more active in an organized tissue of mature alfalfa somatic embryos than in the less-organised tissues of young embryos (Perez-Barranco et al. 2009; Tian et al. 2000).

The number of total embryos was similar for the two promoters (35S CaMV and HEV2.1). The rate of conversion of embryos into plantlets was lower for $35 S C a M V$ than HEV2.1. Finally, that led to produce a low quantity of plantlets for lines harbouring 35S::HbERF-IXc4 compared to lines harbouring $H E V 2.1:: H b E R F-I X c 4$.

Transgenic lines had lower plant regeneration efficiency than wild-type, and lines harbouring $E R F$ genes under the control of the HEV2.1 promoter provided a larger number of plantlets/RITA compared with those under the control of $35 S C A M V$ promoter especially for $H b E R F-I X c 4$ gene. This observation suggests that 
constitutive expression of ERF transgenes decreased regeneration efficiency. By contrast, the use of specific promoter had less effect on somatic embryogenesis process except a stronger callus browning during embryo induction.

\section{Conclusions}

This work described the successful establishment of transgenic lines carrying the two transcription factors HbERF-IXc4 and HbERFIXc5 under the control of $35 S$ CaMV or HEV2.1 promoters. Transgenic lines obtained may lead to better understanding the functional analysis of overexpression of $H b E R F-I X c 4$ and $H b E R F-I X c 5$ by further application of biotic and abiotic stresses and histology analysis.

\section{Acknowledgements}

This work was supported by CIRAD, the Institut Français du Caoutchouc, SIPH and SOCFINDO companies, as well as the Directorate General of Higher Education (DGHE) Ministry of National Education of Indonesia (Scholarship No. 386/E4.4/K/ 2012), French Ministry of Foreign Affair, and AGREENIUM.

\section{References}

Benavente LM \& JM Alonso (2006). Molecular mechanisms of ethylene signaling in Arabidopsis. Mol BioSyst 2(3-4), 165-173.

Blanc G, C Baptiste, G Oliver, Martin \& P Montoro (2006). Efficient Agrobacterium tumefaciens-mediated transformation of embryogenic calli and regeneration of Hevea brasiliensis Mull Arg. plants. Plant Cell Rep 24(12), 724-33.

Clément-Demange A, PM Priyadarshan, TTT Hoa \& P Venkatachalam (2007). Hevea rubber breeding and genetics. In: Janick $\mathrm{J}$ (ed) Plant Breeding Reviews. John Wiley \& Sons, Inc., Hoboken, NJ, USA.

Duan C, X Argout, V Gebelin, M Summo, JF Dufayard, J Leclercq, Kuswanhadi, P Piyatrakul, J Pirrello, M Rio, A Champion \& P Montoro (2013). Identification of the Hevea brasiliensis AP2/ERF superfamily by RNA sequencing. BMC genomics 14, 30.

Duan C, M Rio, J Leclercq, F Bonnot, G Oliver \& P Montoro (2010). Gene expression pattern in response to wounding, methyl jasmonate and ethylene in the bark of Hevea brasiliensis. Tree Physiol 30(10), 1349-1359.

Finer JJ (1988). Plant regeneration from somatic embryogenic suspension cultures of cotton, Gossypium hirsutum L. Plant Cell Rep 7, 399402.

Lardet L, F Dessailly, MP Carron, MA Rio, N Ferriere \& P Montoro (2009). Secondary somatic embryogenesis in Hevea brasiliensis (Mull. Arg.): An alternative process for longterm somatic embryogenesis. J Rub Res 12(4), 215-228.

Lardet L, F Martin, F Dessailly, MP Carron \& P Montoro (2007). Effect of exogenous calcium on post-thaw growth recovery and subsequent plant regeneration of cryopreserved embryogenic calli of Hevea brasiliensis (Mull. Arg.). Plant Cell Rep 26(5), 559-569.

Lardet L, G Piombo, F Oriol, E Dechamp \& MP Carron (1999). Relations between biochemical characteristics and conversion ability in Hevea brasiliensis zygotic and somatic embryos. Can J Bot 77, 1168-1177.

Leclercq J, L Lardet, F Martin, T Chapuset, G Oliver \& P Montoro (2010). The green fluorescent protein as an efficient selection marker for Agrobacterium tumefaciensmediated transformation in Hevea brasiliensis (Mull. Arg). Plant Cell Rep 29(5), 513-522.

Leclercq J, F Martin, C Sanier, A Clement-Vidal, D Fabre, G Oliver, L Lardet, A Ayar, M Peyramard \& P Montoro (2012). Overexpression of a cytosolic isoform of the $\mathrm{HbCuZnSOD}$ gene in Hevea brasiliensis changes its response to a water deficit. Plant Mol Biol 80(3), 255-272.

Leclercq J, T Szabolcs, F Martin \& P Montoro (2015). Development of a new pCAMBIA binary vector using Gateway® technology. Plasmid 81, 50-54.

Lorenzo O, R Piqueras, JJ Sanchez-Serrano \& R Solano (2003). Ethylene Response Factor1 integrates signals from ethylene and jasmonate pathways in plant defense. Plant Cell 15(1), 165-78.

Montoro P, S Lagier, C Baptiste, B Marteaux, V Pujade-Renaud, J Leclercq \& L Alemanno (2008). Expression of the HEV2.1 gene promoter in transgenic Hevea brasiliensis. Plant Cell Tissue Organ Cult 94(1), 55-63.

Montoro P, N Teinseree, P Kongsawadworakul \& N Michaux Ferrière (2000). Effect of exogenous calcium on Agrobacterium tumefaciens-mediated gene transfer in Hevea brasiliensis (rubber tree) friable calli. Plant Cell Rep 9(9), 851-855.

Montoro P, W Rattana, V Pujade-Renaud, N Michaux-Ferriere, Y Monkolsook, R Kanthapura \& S Adunsadthapong (2003). Production of Hevea brasiliensis transgenic embryogenic callus lines by Agrobacterium tumefaciens: Roles of calcium. Plant Cell Rep 21(11), 1095-1102. 
Perera PCD \& N Dahanayake (2015). Effect of callus colour variation and texture in different colchicine conncentrations on the induction of rice polyploids. In: Proceedings of 8th International Research Conference, KDU, Kamburupitiya, pp. 85-87.

Perez-Barranco G, R Torreblanca, IMG Padilla, C Sanchez-Romero, F Pliego-Alfaro \& JA Mercado (2009). Studies on genetic transformation of olive (Olea europaea L.) somatic embryos: I. Evaluation of different aminoglycoside antibiotics for $n p t I I$ selection: II. Transient transformation via particle bombardment. Plant Cell Tissue Organ Cult 97, 243-251.

Piyatrakul P, M Yang, RA Putranto, J Pirrello, F Dessailly, S Hu, M Summo, K Theeravatanasuk, J Leclercq, Kuswanhadi \& P Montoro (2014). Sequence and expression analyses of ethylene response factors highly expressed in latex cells from Hevea brasiliensis. PloS One 9(6), e99367.

Putranto RA, C Duan, Kuswanhadi, T Chaidamsari, $\mathrm{M}$ Rio, $\mathrm{P}$ Piyatrakul, $\mathrm{E}$ Herlinawati, J Pirrello, F Dessailly, J Leclercq, F Bonnot, C Tang, S Hu \& P Montoro (2015). Ethylene response factors are controlled by multiple harvesting stresses in Hevea brasiliensis. PloS One 10(4), e0123618.

Rattana W, N Teinseree, S Tadakittisarn, V Pujade Renaud, Y Mongkolsook, \& P Montoro (2001). Characterization of factors involved in the tissue growth recovery and the sustainability of the GUS activity in Hevea brasiliensis friable calli transformed by
Agrobacterium tumefaciens. Thai J Agric Sci 34(3-4), 195-204.

Sambrook J, EF Fritsch \& TA Maniatis (1989). Molecular cloning: A laboratory manual. Cold Spring Harbor Laboratory Press.

Sen MK, S Nasrin, S Rahman \& AHM Jamal (2014). In vitro callus induction and plantlet regeneration of Achyranthes aspera L., a high value medicinal plant. Asian Pac J Trop Biomed 4(1), 40-46.

Tian L, DCW Brown \& J Webb (2000). Transient expression of a reporter gene changes significantly during somatic embryogenesis in alfalfa. Can J Plant Sci 80, 765-771.

Vaysse L, F Bonfils, J Sainte-Beuve \& M Cartault (2012). Natural rubber. Elsevier 10, 281-292.

Wasternack C \& B Hause (2013). Jasmonates: biosynthesis, perception, signal transduction and action in plant stress response, growth and development. Ann Bot 111(6), 1021-1058.

Weiss D \& N Ori (2007). Mechanism of cross talk between gibberelin and other hormones. Plant Physiol 144(3), 1240-1246.

Wu Y, Y Wang, J Li, W Li, L Zhang, Y Li, X Li, L Zhu \& G Wu (2014). Development of a general method for detection and quantification of the P35S promoter based on assessment of existing methods. Sci Rep, 7358.

Zhu Z \& B Lee (2015). Friends or Foes: New Insights in jasmonate and ethylene co-actions. Plant Cell Physiol 56 (3), 414-420. 